\title{
Article
}

\section{Promising investigational drug candidates in phase I and phase II clinical trials for mesothelioma}

Guazzelli, Alice, Bakker, Emyr, Tian, Kun, Demonacos,

Constantinos, Krstic-Demonacos, Marija and Mutti, Luciano

Available at http://clok.uclan.ac.uk/21181/

Guazzelli, Alice, Bakker, Emyr ORCID: 0000-0002-0091-1029, Tian, Kun, Demonacos, Constantinos, Krstic-Demonacos, Marija and Mutti, Luciano (2017) Promising investigational drug candidates in phase I and phase II clinical trials for mesothelioma. Expert Opinion on Investigational Drugs, 26 (8). pp. 933-944. ISSN 1354-3784

It is advisable to refer to the publisher's version if you intend to cite from the work. http://dx.doi.org/10.1080/13543784.2017.1351545

For more information about UCLan's research in this area go to http://www.uclan.ac.uk/researchgroups/ and search for <name of research Group>.

For information about Research generally at UCLan please go to http://www.uclan.ac.uk/research/

All outputs in CLoK are protected by Intellectual Property Rights law, including Copyright law. Copyright, IPR and Moral Rights for the works on this site are retained by the individual authors and/or other copyright owners. Terms and conditions for use of this material are defined in the policies page.

\section{CLoK}

Central Lancashire online Knowledge www.clok.uclan.ac.uk

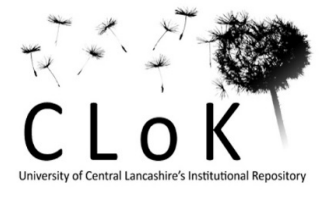




\section{Promising investigational drug candidates in phase I and phase II clinical trials for mesothelioma}

Guazzelli Alice ${ }^{1}$, Bakker Emyr ${ }^{1}$, Tian Kun ${ }^{1}$, Demonacos Constantinos ${ }^{2}$, Krstic-Demonacos Marija ${ }^{1}$, Mutti Luciano ${ }^{1}$

1 Biomedical Research Centre, School of Environment and Life Sciences, University of Salford, United Kingdom.

2 School of Health Sciences, University of Manchester, United Kingdom

Electronic address: L.Mutti@salford.ac.uk 


\begin{abstract}
Introduction: Malignant mesothelioma is a rare and lethal malignancy primarily affecting the pleura and peritoneum. Mesothelioma incidence is expected to increase worldwide and current treatments remain ineffective, leading to poor prognosis. Within this article potential targets to improve the quality of life of the patients and assessment of further avenues for research are discussed.
\end{abstract}

Areas covered: This review highlights emerging therapies currently under investigation for malignant mesothelioma with a specific focus on phase I and phase II clinical trials. Three main areas are discussed: immunotherapy (immune checkpoint blockade and cancer vaccines, among others), multitargeted therapy (such as targeting pro-angiogenic genes) and gene therapy (such as suicide gene therapy). For each, clinical trials are described to detail the current or past investigations at phase I and II.

Expert opinion: The approach of applying existing treatments from other cancers does not show significant benefit, with the most promising outcome being an increase in survival of 2.7 months following combination of chemotherapy with bevacizumab. It is our opinion that the hypoxic microenvironment, the role of the stroma, and the metabolic status of mesothelioma should all be assessed and characterised to aid in the development of new treatments to improve patient outcomes.

\begin{tabular}{|c|c|}
\hline mom & box \\
\hline & $\begin{array}{l}\text { Since the success of immune checkpoint inhibitors and cancer vaccines approved by the } \\
\text { FDA for the treatment of cancers such as melanoma, immunotherapy may be evaluated } \\
\text { as a third-line therapy for cancer treatment after conventional treatments and targeted } \\
\text { agents. }\end{array}$ \\
\hline & $\begin{array}{l}\text { Mesothelin is one of the main targets in immunotherapeutic approaches but the efficacy } \\
\text { of this strategy is still poor. }\end{array}$ \\
\hline & $\begin{array}{l}\text { CTLA-4 and PD1/L1 blockage are widely investigated in numerous clinical trials as single or } \\
\text { combined therapy in mesothelioma patients but the outcome is still unsatisfactory }\end{array}$ \\
\hline & $\begin{array}{l}\text { Main targeted therapies against EGFR and VEGFA/VEGFR showed no clinical activity in } \\
\text { mesothelioma patients and only slightly promising results have been shown in patients } \\
\text { treated with bevacizumab in combination with chemotherapy. }\end{array}$ \\
\hline & $\begin{array}{l}\text { It is our belief that to improve current therapies the role of the hypoxic microenvironment } \\
\text { and influence of the stroma in chemoresistance should be further characterised, in } \\
\text { addition to uncovering the extent of metabolic reprogramming that occurs in tumours } \\
\text { cells. }\end{array}$ \\
\hline
\end{tabular}

Keywords: Malignant mesothelioma, immunotherapy, targeted therapy and gene therapy 


\section{Introduction}

Malignant mesothelioma (MM) is a lethal and rare malignancy arising from surface mesothelial cells lining cavities such as pleura (malignant pleural mesothelioma, MPM, approximately $80 \%$ of cases), peritoneum (approximately $20 \%$ of cases) whilst less than $1 \%$ of cases occur in the pericardium and tunica vaginalis ${ }^{1,2}$. The major common risk factor for $\mathrm{MM}$ is asbestos exposure but radiation and simian virus 40 (SV40) have also been implicated as additional risk factors for $\mathrm{MM}^{3}$. Recently, it has been reported that BRCA1 associated protein-1 (BAP1) mutation could be a genetic predisposition to $\mathrm{MM}^{4}$. MM is characterised by a long latency period (20-40 years) before the symptoms occur. The symptoms themselves are non-specific, which makes this tumour difficult to diagnose and the disease itself has a poor prognosis; the median survival rate is less than twelve months ${ }^{5}$ and only $10-20 \%$ of cases present life expectancy of 5 -years ${ }^{6}$. The worldwide incidence rate is increasing and a peak is expected between 2015-2030. A study on mesothelioma frequency between 19942008 reported a global average of 14,200 cases each year ${ }^{7}$. The USA, UK, Australia and Italy all report high incidence rates. In industrialized countries, where asbestos is used illegally, the incidence frequency is expected to increase, thus affecting the global incidence ${ }^{8}$. There is generally a lack of curative treatments for MM patients. Systemic treatment in the form of chemotherapy, radiotherapy and targeted therapy are options as single treatment or in combination in a multimodality regimen ${ }^{8}$. Surgery is debatable and is recommended only in patients with early stage disease and in a good general health. A number of novel therapeutic drugs are under investigation, and may provide further treatment options for $M M$ in the future. In this review, we will summarise current clinical trials and highlight promising agents, giving an overall opinion from a translational research team.

\section{Novel Therapeutics Under Investigation for Mesothelioma}

There are 256 clinical trials for MM currently reported in ClinicalTrials.gov, including recruiting, completed, active and terminated studies as single intervention or in combination modality. The main categories of agents investigated include immunotherapeutics, gene therapy, and multiple targeted therapies. Different approaches will be discussed in turn throughout this manuscript, in addition to describing phase I and phase II trials for them.

\subsection{Immunotherapy}

Recently, immunotherapy, including active and passive therapeutic strategies has acquired a significant interest in the field of cancer treatment. Active strategies utilise for example tumour-specific antigens to trigger a direct immune system response such as cancer vaccines 9. Passive approaches use an activated immune cell effector component such as immunomodulators (including cytokines) and tumour-specific antibodies to target tumour 
antigens without direct stimulation of the immune system ${ }^{10}$, whilst adoptive cellular therapy aims to administer genetically modified immune cells directly to patients ${ }^{11}$. For decades immunotherapy has reported clinical failures but recently the development of new molecules such as immune checkpoint inhibitors have shown promising results, leading to the approval of immune checkpoint inhibitors for the treatment of melanoma. Cytotoxic T-lymphocyte antigen 4 (CTLA-4; CD152) is a key immune checkpoint and serves to downregulate immune responses, as does programmed death-1/programmed death ligand-1 (PD-1/PDL-1). Antibodies such as ipilimumab and nivolumab have been developed against CTLA-4 and PD1 respectively and were approved for the treatment of melanoma in 2011 and 2014 respectively ${ }^{9}$. The most common use of immunotherapy is as part of combination therapy with other conventional and non-conventional approaches which aim to achieve enhanced efficacy with a diminished toxic effect, thus modulating a durable and adaptable cancer control response. Preclinical studies suggest a potential for synergistic effects on tumour response and overall survival (OS) in multimodality treatment with agents that target different immune checkpoints ${ }^{12}$. However, combination immunotherapy against multiple checkpoints has also demonstrated a high rate of side-effects, such as one study combining nivolumab and ipilimumab for the treatment of melanoma which showed side-effects at grade three or four in $55 \%$ of patients ${ }^{13}$. At present, immunotherapy is typically evaluated as a third-line for cancer therapy after conventional treatments and targeted agents. Trials relating to immunotherapy are summarised in Table 1 and Table 2.

\subsubsection{Cancer Vaccines}

The main aim of cancer vaccination is to educate immune system to recognise cancer cells, which exhibit specific tumour antigens, thereby restoring or promoting the ability of the immune system, mainly by CD8+ cytotoxic T cell activation, to fight cancer cells ${ }^{14}$. Several subcategories of vaccines have been developed, detailed below in the subsequent sections.

\subsubsection{Dendritic-Cell-Based Vaccines}

A common approach in vaccine immunotherapy is the use of dendritic cells (DCs) loaded with tumour-associated antigens. DCs are a heterogeneous population of antigen-presenting cells (APCs) and are specialized in processing proteins, which leads to the subsequent presentation of antigens. Production of autologous DCs is carried out through ex vivo differentiation from peripheral blood precursors, followed by maturation of DCs to activate them ${ }^{15}$. Before being injected in the patients DCs are loaded with tumour lysates derived from patients either via viral infection or grown in media containing antigenic peptides ${ }^{16}$. Upon infusion into the patient, the activated DCs generate anti-tumour T-cell responses due to CD4+ T cells activating CD8+ effector T-cells (Fig 1). In April 2010, the FDA approved Sipuleucel-T (PROVENGE; Dendreon) as the first therapeutic cancer vaccine for use in patients who have metastatic castration-resistant prostate cancer ${ }^{17}$. The success of this vaccine is related to the increase of OS, although the disease progression was unchanged, giving an additional treatment option for patients with prostate cancer ${ }^{18}$. However, ex vivo 
therapies such as PROVENGE had a limited practical use in other cancer types and produced an immune response with limited scope ${ }^{19}$.

\subsubsection{Peptide or Protein-Based Vaccines}

Peptide/protein vaccines are based on the principle of stimulating CD8+ T cells to promote an anti-tumour effect, and consist of five broad categories: mutated antigens expressed only by the tumours; overexpressed normal self-antigens; oncofoetal antigens which are present in foetal tissues as well as some adult tumours; differentiation or lineage antigens; and cancertestis antigens ${ }^{20-22}$ (Fig 2). Among these, an interesting target is Wilms tumour gene (WT1) protein, which is highly expressed in various tumours, including mesothelioma and is associated with oncogenic function, providing a strong rationale to consider WT1 as an attractive target for cancer immunotherapy ${ }^{23}$. An additional common target is mesothelin, a cell-surface antigen associated with tumour invasion, which is highly expressed in several solid tumours such as mesothelioma and has been targeted in immunotherapy approaches due to the fact that its expression is low in normal mesothelial cells. Cancer vaccines developed against mesothelin use a live attenuated Listeria monocytogenes-expressing mesothelin (CRS-207, JNJ-64041757). Numerous antigens with promising potential are under investigation in few cancers ${ }^{24}$. 5T4 vaccine (TroVax®) targets an oncofoetal antigen called 5T4 which is inserted in an attenuated modified vaccinia ankara (MVA) virus. 5T4 is upregulated in cancer with a limited expression in normal tissue and is associated with epithelial mesenchymal transition (EMT), contributing to metastasis of epithelial cancers ${ }^{24}$. Thus, this represents an interesting target for therapeutic development.

\subsubsection{Phase I Clinical Trials}

A preliminary study on murine malignant mesothelioma model showed that immunotherapy using tumour lysate-pulsed dendritic cells controlled MM outgrowth ${ }^{25}$. Following this a phase I study investigated the safety and immunological response after the administration of tumour lysate-pulsed dendritic cells in MPM patients. The results showed a well-tolerated profile, with the treatment inducing an immunological response to tumour cells in MPM patients (NCT00280982) ${ }^{26}$. Further, to investigate whether the combination of low-dose cyclophosphamide with autologous tumour lysate-pulsed dendritic cells was advantageous compared to monotherapy, the effect of this combination on the suppressive function of regulatory $\mathrm{T}$ cells was assessed in $10 \mathrm{MPM}$ patients. This approach demonstrated disease control and a well-tolerated profile (NCT01241682) ${ }^{27}$.

Another pilot study was designed to assess the safety profile and efficacy of tumour cell vaccines in combination with the chemotherapeutic compound cyclophosphamide and the anti-inflammatory drug celecoxib in patients with mesothelioma. The study has been completed and 10 patients have been enrolled but the data are not available yet (NCT01143545). An additional pilot study investigated the safety and immunogenicity profile of a WT1 vaccine in patients with thoracic neoplasms (mesothelioma and non-small cell lung 
cancer (NSCLC)) expressing WT1 ${ }^{28}$. Each vaccine dose was prepared by mixing equal volumes of adjuvant Montandine 51 with $200 \mu \mathrm{g}$ each of four different peptide sequences known to bind MHC molecules and stimulate T cell responses ${ }^{28} .200 \mu \mathrm{g}$ was chosen as it is a known safe and active concentration. Injection sites were pre-stimulated with sargramostim (GM-CSF, granulocyte-macrophage colony-stimulating factor) and vaccines were administered subcutaneously ${ }^{28}$. The immune response was stimulated in most of the patients, showing the ability of $\mathrm{T}$ cells to exert a cytotoxic effect against WT-1 positive cells. Therefore, a randomized II phase trial has been planned ${ }^{28}$. Phase I clinical trials have been recently completed or are still ongoing testing the safety of WT1-based vaccines (NCT00398138) which evaluate WT1 vaccination in conjunction with conventional chemotherapy (NCT02649829). The outcome of completed studies showed the vaccination promoted a tumour-specific immunity (both cellular and humoral) and was safe but a clinical response was not observed ${ }^{29}$. A phase I study tested CRS-207 (vaccine targeting mesothelin which is widely expressed on cancer cells) with chemotherapy in 38 patients. The clinical outcome showed that CRS-207 was well-tolerated and in combination with pemetrexed and cisplatin showed an anti-tumour activity with $59 \%$ of patients achieving an objective partial response and median progression free survival (PFS) of 8.5 months $\left(\underline{\text { NCTO1675765) }}{ }^{30}\right.$.

\subsubsection{Phase II Clinical Trials}

A pilot study investigated the clinical effects of cyclophosphamide in combination with autologous or allogeneic tumour cell vaccines to treat patients with various advanced cancers including mesothelioma (NCTO0002475). An ongoing phase II study is evaluating treatment with the WT-1 peptide vaccine in combination with Montanide/GM-CSF versus Montanide/GM-CSF alone in patients with MPM who have completed multimodality therapy (NCT01265433).

Table 1: Examples of Phase I and II clinical trials for vaccine immunotherapy.

\begin{tabular}{|c|c|c|c|}
\hline$\underline{\text { ClinicalTrials.gov }}$ & Phase & $\underline{\text { Treatment }}$ & $\underline{\underline{\text { Number of }}}$ \\
\hline$\underline{\text { NCT00280982 }}$ & I & $\begin{array}{c}\text { Autologous dendritic } \\
\text { cells }\end{array}$ & 10 \\
\hline$\underline{\text { NCT01241682 }}$ & I & $\begin{array}{c}\text { Autologous dendritic } \\
\text { cells + low-dose } \\
\text { cyclophosphamide }\end{array}$ & 10 \\
\hline NCT01143545 & I & $\begin{array}{c}\text { Tumour cell vaccine } \\
\text { in combination with } \\
\text { cyclophosphamide } \\
\text { and the anti- } \\
\text { inflammatory drug }\end{array}$ & 10 \\
\hline
\end{tabular}




\begin{tabular}{|c|c|c|c|}
\hline & & celecoxib & \\
\hline$\underline{\text { NCT00398138 }}$ & I & $\begin{array}{l}\text { Wilms' tumour-1 } \\
\text { (WT-1) vaccine, with } \\
\text { injection sites being } \\
\text { pre-stimulated by } \\
\text { sargramostim (GM- } \\
\text { CSF) }\end{array}$ & 22 \\
\hline NCT02649829 & $\mathrm{I} / \mathrm{II}$ & $\begin{array}{l}\text { Autologous dendritic } \\
\text { cells loaded with WT- } \\
1 \text { antigen in } \\
\text { conjunction with } \\
\text { conventional } \\
\text { chemotherapy }\end{array}$ & $\begin{array}{l}\text { Currently } \\
\text { recruiting }\end{array}$ \\
\hline NCT01675765 & I & $\begin{array}{c}\text { Cancer vaccine CRS- } \\
207 \text { (attenuated } \\
\text { Listeria } \\
\text { monocytogenes) with } \\
\text { or without } \\
\text { cyclophosphamide }\end{array}$ & 60 \\
\hline$\underline{\text { NCT00002475 }}$ & II & $\begin{array}{l}\text { Cyclophosphamide in } \\
\text { combination with } \\
\text { tumour cell vaccine }\end{array}$ & 40 \\
\hline$\underline{\text { NCT01265433 }}$ & II & $\begin{array}{l}\text { Either non-specific } \\
\text { immunotherapy } \\
\text { (montanide and } \\
\text { sargramostim) or WT- } \\
1 \text { vaccine, montanide } \\
\text { and sargramostim }\end{array}$ & 31 \\
\hline
\end{tabular}

\subsubsection{Antibody-Based Therapies}

One extensively investigated approach to overcome the toxicity of currently-used chemotherapies is the use of monoclonal antibodies (mAbs), which have the ability to precisely target malignant cells overexpressing specific surface antigens ${ }^{31}$ (Fig 3A). Rituximab (anti-CD20 $\underline{\mathrm{mAb}}$ ) is the first approved $\mathrm{mAb}$ for the treatment of cancer, raising the interest in the development of a number of actively pursued antibody (Ab)-based technologies, including immunotoxins, radioimmuno-therapeutics, and immunoliposomes ${ }^{32}$.

The main antibodies tested in clinical trials target mesothelin such as immunotoxins and chimeric antimesothelin antibodies (i.e. amatuximab) ${ }^{33}$. Antimesothelin immunotoxin $\mathrm{SS} 1(\mathrm{dsFv}) \mathrm{PE} 38$ (SS1P) is a recombinant molecule with a murine antimesothelin variable antibody fragment (Fv) linked to PE38, a truncated portion of Pseudomonas exotoxin A. In 
preclinical models, SS1P reduced mesothelin-expressing tumors, both alone and in combination with chemotherapy and radiation therapy ${ }^{34}$. Amatuximab (MORAb-009) is a chimeric monoclonal antibody with a high affinity for human mesothelin $\left(\mathrm{K}_{\mathrm{D}}=1.5 \mathrm{nM}\right){ }^{33,35}$. Preclinical studies showed that amatuximab induces cell-mediated cytotoxicity in tumour cells expressing mesothelin ${ }^{36}$. Moreover, using toxicological analyses it has been demonstrated that amatuximab did not cause any adverse effects in mouse models ${ }^{36}$. Anetumab ravtansine (BAY 94-9343) is another antibody under investigation in MPM patients overexpressing mesothelin. An in vitro study demonstrated that anetumab exerts potent and selective cytotoxicity against mesothelin-expressing cells ${ }^{37}$. A model study reported that anetumab interacts with mesothelin-positive tumours and inhibits tumour growth in xenograft models ${ }^{37}$.

GC1008 is a human anti-TGF $\beta$ monoclonal antibody that counteracts all isoforms of TGF $\beta$ thereby preventing tumour growth and metastasis ${ }^{38,39}$. Preclinical data of TGF $\beta$ blockade in animal models of MPM and in human MPM cell lines suggest that TGF $\beta$ inhibitors can be effective therapeutic agents. In addition, high levels of TGF $\beta$ were found in rat and murine MPM cells as well as in tumours and in pleural effusions of MPM patients ${ }^{40}$. However, cost limitations, inadequate pharmacokinetics and tissue accessibility all contribute to the need for further investigation and improvement of this approach ${ }^{41}$.

\subsubsection{Cytokine-Based Therapy}

Cytokine-based immunotherapy aims to stimulate a cytotoxic immune response which involves stimulation of non-specific natural killer cells or highly specific cells such as cytotoxic T cells or Tumour Infiltrating Lymphocytes ${ }^{42}$ (Fig 3B). Interleukin-2 (IL-2) is the first cytokine successfully used in clinical therapy but a small proportion of cancers can benefit from this approach and a complete clinical response occurs rarely ${ }^{43}$. Among immunotherapeutic cytokines investigated as potential treatments are interferons $(\alpha, \beta, \gamma)$, which lead to an immune response with a significant toxic effect against tumour cells ${ }^{42}$. In MPM, INFץ may contribute to a direct cytotoxic effect on mesothelial cells and stimulate NK and macrophages 44 .

\subsubsection{Phase I Clinical Trials}

A phase I trial of SS1P (which exerts its effects via targeting of mesothelin and Pseudomonas exotoxin A) aimed to verify the side effects and best dose of this immunotoxin approach in treating patients with recurrent unresectable advanced solid tumours, including MPM (NCT00066651) $^{45} .24$ patients with different cancer types (9 with pleural mesothelioma, 5 with peritoneal mesothelioma and 2 with pleural-peritoneal mesothelioma) were enrolled and the clinical outcome of this single therapy presented a well-tolerated profile up to $25 \mu \mathrm{g} / \mathrm{kg} / \mathrm{d}$ $\times 10$ and exhibited a modest clinical activity, with $75 \%$ of patients exhibiting immunogenicity and $21 \%$ receiving a second cycle. One patient had a partial response, twelve had stable disease, and eleven had progressive disease ${ }^{45}$. Another clinical trial evaluated the safety and tumour response of SS1P in combination with pemetrexed and cisplatin in 24 patients with 
advanced MPM. SS1P given with pemetrexed and cisplatin had a safe and well tolerated clinical profile and showed significant antitumor activity with a partial response in $60 \%$ of patients (NCT01445392) ${ }^{46}$. A phase 1 study was conducted to assess the safest doses of amatuximab in patients with mesothelin-positive cancers (pancreatic, ovarian, mesothelioma and lung) (NCT00325494). Amatuximab exhibited a well-tolerated profile and the maximum tolerated dose (MTD) was chosen at $200 \mathrm{mg} / \mathrm{m}^{2}{ }^{47}$. Another study investigated the doselimiting toxicity and estimated MTD involving 17 patients with mesothelin-positive cancer, including mesothelioma patients (NCT01018784). Amatixumab was well-tolerated and MTD was determined to be $200 \mathrm{mg} / \mathrm{m}^{2}$ in agreement with the study mentioned above ${ }^{48}$. A completed study investigating treatment with INF- $\alpha$ combined with cisplatin, surgery and radiotherapy in 6 MPM patients has also been performed, though results are not yet published (NCT00003263).

\subsubsection{Phase II Clinical Trials}

An open-label multicentre clinical trial investigated amatuximab plus pemetrexed and cisplatin for the treatment of 89 MPM patients. PFS and overall response (OR) were the endpoints for this study ( safety profile, exploration in other mesothelin-expressing cancers may be justified. A Phase II investigation of GC1008 to assess the overall safety and effectiveness in 13 patients with MPM has also been performed, which demonstrated that the drug was generally welltolerated in MPM patients (NCT01112293). However, partial or complete radiographic responses were not achieved and stable disease was observed in only 3 subjects. Patients who produced anti-TGF $\beta$ antibodies had increased median OS (15 vs 7.5 months, $p<0.03){ }^{40}$.

\subsubsection{Adoptive T Cell Therapy}

Adoptive immunotherapy uses genetically enhanced $\mathrm{T}$ cells to trigger a potent and tumourspecific immune effect that affects small or large tumour burdens. The advantage of this approach is that it should avoid side effects and toxicities associated with standard approaches such as chemotherapy ${ }^{50}$. T cells are engineered to express a tumour antigen by the integration of genes encoding conventional T-cell receptors (TCRs) or chimeric antigen receptors (CARs, receptors which may undertake MHC-independent targeting and thus combine the targeting specificity of antibodies and the cytotoxicity of T cells) ${ }^{50,51}$ (Fig 3C). One of the most attractive CAR T cell applications is targeting overexpressed mesothelin in solid tumours, including mesothelioma ${ }^{34}$. It has been shown that adoptive transfer of engineered antimesothelin human CAR $\mathrm{T}$ cells regressed large human MPM xenograft tumors in immunodeficient mice in preclinical models ${ }^{52}$. Alternatively, CAR T cells were used to target non-transformed stromal cells, which promote cancer. CAR $\mathrm{T}$ cells were directed against fibroblast activation protein (FAP), which is overexpressed on the surface of reactive tumor-associated fibroblasts ${ }^{53}$. High level of FAP expression in tumour tissue of MPM patients has been reported highlighting the potential of using adoptive T-cell therapy as 
an effective approach to treat MPM ${ }^{53}$. Another class of adoptive immunotherapy is the use of tumour infiltrating lymphocytes (TILs) which are engineered in vitro with affinity $\mathrm{T}$ cell receptors against major tumour antigens. One application of TIL therapy is using TILs in combination with high-dose interleukin-2 which has demonstrated a activity in several clinical trials, showing durable clinical response rates near $50 \%$ or more, though toxicities and side effects associated with interleukin-2 treatment have also been observed ${ }^{54,55}$.

\subsubsection{Phase I Clinical Trials}

A clinical trial of CAR T cells targeting mesothelin is recruiting participants with metastatic cancers, including mesothelioma. The purpose of this study is to evaluate the safe number of enhanced $\mathrm{T}$ cells to infuse and effective doses in an estimated number of 136 subjects (NCT01583686). Another recruiting clinical trial aims to use redirected T cells against FAP to assess the safety of a fixed single dose by direct injection in the pleural effusion for patients (estimated number of six) with MPM not eligible for surgery (NCT01722149). A Phase I/II evaluating cell infusion after administration of cyclophosphamide and fludarabine with lowdose interleukin-2 therapy is currently under investigation (든2414945).

\subsubsection{Immune Checkpoint Treatment}

Cytotoxic T-lymphocyte antigen 4 (CTLA-4; CD152) receptor and programmed death1/programmed death ligand-1 (PD1/PDL-1) are the major immune checkpoints targeted for clinical studies ${ }^{56,57}$ (Fig 3D). The biological role of immune checkpoints is to negatively regulate the immune response by downregulating $\mathrm{T}$-cell function resulting in immune tolerance to self-antigens, and balancing the immune response ${ }^{58,59}$. CTLA-4 exerts its inhibitory signal through competition with its positive counterpart, CD28, for its ligand B7 ${ }^{59}$. A preclinical study reported that CTLA-4-deficient mice die due to lethal lymphoproliferation ${ }^{60}$ whilst a later study showed that blockade of CTLA-4 did not cause lethal systemic autoimmunity and promoted an antitumour effect ${ }^{61}$ This preclinical rationale justified the development of two main immune checkpoint blockers: ipilimumab (known as MDX-010 or BMS-734016; Yervoy ${ }^{\mathrm{TM}}$, Bristol-Myers Squibb, Princeton, NJ), a fully human, IgG1 monoclonal antibody (mAb) which binds CTLA-4. Ipilimumab was the first immune checkpoint blockage therapy approved for treatment of metastatic melanoma in $2011^{62}$. Ipilimumab was also approved by the Food and Drug Administration (FDA) as adjuvant for stage III melanoma ${ }^{62}$. Tremelimumab (CP-675 206 or ticilimumab; Pfizer Inc, New York, $\mathrm{NY}$, USA) is a humanized IgG2 mAb against CTLA-4 that has also been used in clinical trials, detailed below ${ }^{63}$.

Following the promising results of CTLA-4 blockage, other immune checkpoints such as the PD-1/PD-L1 pathway have been targeted. PD-1 is a negative regulator of T-cells since by interacting with the PD-L1 and the PD-L2 ligands limits their activity. Several therapeutic agents have been developed against PD-1 and PD-L1 but the development of autoimmune diseases has been observed in PD-1-deficient mice in preclinical studies ${ }^{64}$. Nivolumab known also as MDX-1106, BMS-936558, and ONO-4538; Opdivo®, Bristol-Myers Squibb, 
Princeton, NJ) is a humanized IgG4 mAb. Nivolumab has been approved by FDA for the treatment of Hodgkin lymphoma ${ }^{65}$, unresectable or metastatic melanoma ${ }^{66}$ and metastatic NSCLC 67. Another therapy targeting PD-1 which has been clinically tested is pembrolizumab (MK-3475, lambrolizumab; Keytruda ${ }^{\circledR}$, Merck, Whitehouse Station, NJ) which is an IgG4 engineered humanized Ab, approved in 2014 for the treatment of metastatic melanoma ${ }^{68}$ and in 2015 for NSCLC ${ }^{69}$.

Other drugs targeting PD-L1 such as atezolizumab (MPDL3280A; Tecentriq ${ }^{\circledR}$, Genentech, Inc, South San Francisco, CA), an IgG1 humanized, engineered $\mathrm{mAb}$, has also been developed. In October 2016 the FDA approved atezolizumab for NSCLC. Avelumab (MSB0010718C,EMD Serono, Rockland, MA) is a fully human IgG1 monoclonal PD-L1 antibody.

Recently, another component of the B7 family, called B7-H3 (CD276), has been shown to regulate the immune response being involved in the inhibition of the signalling of the T-reg cells. B7-H3 is over-expressed in a wide variety of solid tumour types ${ }^{70}$. Enoblituzumab (MGA271,) is an Fc-optimized humanized IgG1 mAb that binds to B7-H3 and has also been used in clinical trials, detailed in subsequent sections. B7-H3 is a negative immune checkpoint and it has been shown that its blockage can promote an anti-tumour immune response ${ }^{71}$

All of these immune checkpoint blockage therapies have been or are under investigation in MPM in phase I or phase II studies as described below.

\subsubsection{Phase I}

Several phase I clinical trials have been designed to evaluate pembrolizumab in combination with standard chemotherapy, radiotherapy (NCT02959463) or novel strategies such as defactinib (a focal adhesion kinase (FAK) inhibitor) (NCT02419495 and NCT02758587). Some of them are currently recruiting and the main aim is to evaluate the safety of the combination of pembrolizumab in combination with standard chemotherapy (NCT02707666) in particular as a window of opportunity pilot trial of pembrolizumab in patients affected by resectable malignant pleural mesothelioma. One study is investigating the combination of pembrolizumab with an antiangiogenesis agent (nintedanib) since antiangiogenic therapy may synergize with immunotherapy, thus offering a benefit for the quality of life of patients with advanced solid tumours, including MPM (NCT02856425). First considerations about the clinical profile of pembrolizumab has been presented at the AACR Annual Meeting 2015 with a phase Ib study (KEYNOTE-028: NCT02054806). Published data related to this clinical trial showed that only five patients $(20 \%)$ had a partial response and thirteen $(52 \%)$ had stable disease and sixteen patients $(64 \%)$ showed a treatment-related adverse event ${ }^{72}$.

The PD-L1 inhibitor avelumab is under investigation in a phase I study that is currently recruiting patients with solid tumours including malignant mesothelioma (JAVELIN Solid Tumor: NCT01772004). Investigational studies of combined immunotherapy approaches are currently recruiting patients and are a phase I study of a combination modality of ipilimumab with enoblituzumab in refractory cancers, including MM (NCT02381314). Another phase I 
study evaluates the safety of enoblituzumab in combination with pembrolizumab in refractory cancers such as malignant mesothelioma (든2475213).

\subsubsection{Phase II Clinical Trials}

The success of ipilimumab and its approval for the treatment of metastatic melanoma, plus the promising clinical efficacy of immunotherapy in combination with other treatments, has led to the investigation of ipilimumab in two phase II studies in combination with nivolumab (NCT03048474 and NCT02716272). The combination treatment with two different immune checkpoint inhibitors may delay tumour progression in patients with unresectable malignant pleural mesothelioma. However, the central immune checkpoint tested in mesothelioma is tremelimumab which has been investigated mainly as single dose in three phase II studies. A phase II study of tremelimumab in patients with chemotherapy-resistant advanced malignant mesothelioma ( $\underline{\text { NCT01649024) }}$ has been carried out. Tremelimumab showed an adequate safety and tolerability profile although only 29 patients were enrolled and no patients achieved a complete response and only two patients (7\%) exhibited a durable partial response (one of 6 months and one of 18 months) ${ }^{73}$. Another phase II trial assessed the efficacy and safety of an intensified schedule of tremelimumab in patients with unresectable advanced malignant mesothelioma (NCT01655888). In this study, 3\% (one patient) achieved a partial response and 38\% (11 patients) achieved disease control rate. Gastrointestinal and dermatological effects, as well as fever, were the major adverse effects observed that were related to treatment ${ }^{74}$. The results showed a well-tolerated and safe profile that led to the use of the same intensified schedule in an ongoing randomised, double-blind, placebo-controlled, phase $2 \mathrm{~b}$ study (NCT01843374). Tremelimumab has been selected for a combined therapy with another immune checkpoint targeting PD-L1 (MEDI4736). Two clinical studies are currently recruiting participants (

Nivolumab is also under investigation in an ongoing phase II study as monotherapy in patients previously treated with chemotherapy with mesothelioma ( Preliminary data from 38 patients has been released; five patients had reported a partial response; 12 had stable disease and 17 progressive disease and grade 3 toxicity is reported in 8 patients leading to discontinuation of the treatment ${ }^{75}$. Recent recruiting clinical studies evaluate the activity of pembrolizumab as a monotherapy in malignant mesothelioma ( (NCT02784171). Atezolizumab is under assessment in a recruiting phase II study in advanced solid tumours, including mesothelioma (NCT02458638).

Table 2: Phase I and phase II clinical trials for other immunotherapeutic approaches.

\begin{tabular}{|c|c|c|c|}
\hline$\frac{\text { ClinicalTrials.gov }}{\underline{\text { Identifier }}}$ & $\underline{\text { Phase }}$ & $\underline{\text { Treatment }}$ & $\frac{\text { Number of }}{\underline{\text { Patients }}}$ \\
\hline$\underline{\text { NCT00066651 }}$ & I & SS1(dsFv)-PE38 & 24 \\
\hline
\end{tabular}




\begin{tabular}{|c|c|c|c|}
\hline & & immunotoxin & \\
\hline NCT01445392 & I & $\begin{array}{l}\mathrm{SS} 1(\mathrm{dsFv})-\mathrm{PE} 38 \text { in } \\
\text { addition to cisplatin } \\
\text { and pemetrexed }\end{array}$ & 24 \\
\hline NCT00325494 & $\mathrm{I}$ & Amatuximab & 24 \\
\hline NCT01018784 & 1 & Amatuximab & 17 \\
\hline$\underline{\text { NCT00003263 }}$ & $\mathrm{I}$ & $\begin{array}{l}\text { INF- } \alpha \text { combined with } \\
\text { chemotherapy, } \\
\text { radiotherapy and } \\
\text { surgery }\end{array}$ & 6 \\
\hline NCT00738582 & II & Amatuximab & 89 \\
\hline$\underline{\text { NCT01112293 }}$ & II & GC1008 (anti-TGF) & 14 \\
\hline NCT01583686 & $\mathrm{I} / \mathrm{II}$ & $\begin{array}{c}\text { Anti-mesothelin CAR } \\
\text { T cells }\end{array}$ & $\begin{array}{l}\text { Currently } \\
\text { recruiting }\end{array}$ \\
\hline$\underline{\text { NCT01722149 }}$ & I & $\begin{array}{c}\text { Redirected anti-FAP } \\
\text { T cells }\end{array}$ & $\begin{array}{l}\text { Currently } \\
\text { recruiting }\end{array}$ \\
\hline$\underline{\text { NCT02959463 }}$ & I & $\begin{array}{c}\text { Adjuvant } \\
\text { pembrolizumab after } \\
\text { radiation therapy }\end{array}$ & $\begin{array}{l}\text { Currently } \\
\text { recruiting }\end{array}$ \\
\hline NCT02419495 & $\mathrm{I}$ & $\begin{array}{c}\text { Numerous (including } \\
\text { pembrolizumab and } \\
\text { selinexor) }\end{array}$ & 142 \\
\hline NCT02758587 & $\mathrm{I} / \mathrm{II}$ & $\begin{array}{l}\text { Defactinib and } \\
\text { pembrolizumab }\end{array}$ & $\begin{array}{l}\text { Currently } \\
\text { recruiting }\end{array}$ \\
\hline NCT02707666 & I & $\begin{array}{l}\text { Pembrolizumab in } \\
\text { combination with } \\
\text { cisplatin and } \\
\text { pemetrexed }\end{array}$ & $\begin{array}{l}\text { Currently } \\
\text { recruiting }\end{array}$ \\
\hline$\underline{\mathrm{NCT} 02856425}$ & I & $\begin{array}{l}\text { Nintedanib and } \\
\text { pembrolizumab }\end{array}$ & $\begin{array}{l}\text { Currently } \\
\text { recruiting }\end{array}$ \\
\hline NCT02054806 & I & Pembrolizumab & 477 \\
\hline NCT01772004 & I & Avelumab & $\begin{array}{l}\text { Currently } \\
\text { recruiting }\end{array}$ \\
\hline$\underline{\text { NCT02381314 }}$ & $\mathrm{I}$ & $\begin{array}{l}\text { Enoblituzumab in } \\
\text { combination with } \\
\text { ipilimumab }\end{array}$ & $\begin{array}{l}\text { Currently } \\
\text { recruiting }\end{array}$ \\
\hline
\end{tabular}




\begin{tabular}{|c|c|c|c|}
\hline$\underline{\mathrm{NCT} 02475213}$ & $\mathrm{I}$ & $\begin{array}{l}\text { Enoblituzumab in } \\
\text { combination with } \\
\text { pembrolizumab }\end{array}$ & $\begin{array}{l}\text { Currently } \\
\text { recruiting }\end{array}$ \\
\hline NCT03048474 & II & $\begin{array}{l}\text { Nivolumab and } \\
\text { ipilimumab }\end{array}$ & $\begin{array}{l}\text { Currently } \\
\text { recruiting }\end{array}$ \\
\hline$\underline{\mathrm{NCT} 02716272}$ & II & $\begin{array}{l}\text { Nivolumab } \\
\text { monotherapy or } \\
\text { nivolumab in } \\
\text { conjunction with } \\
\text { ipilimumab }\end{array}$ & 125 \\
\hline NCT01649024 & II & Tremelimumab & 29 \\
\hline NCT01655888 & II & Tremelimumab & 29 \\
\hline NCT01843374 & II & Tremelimumab & 658 \\
\hline NCT02588131 & II & $\begin{array}{c}\text { Tremelimumab in } \\
\text { combination with } \\
\text { MEDI4736 (anti-PD- } \\
\text { L1) }\end{array}$ & $\begin{array}{l}\text { Currently } \\
\text { recruiting }\end{array}$ \\
\hline NCT02592551 & II & $\begin{array}{l}\text { MEDI4736 or } \\
\text { MEDI4736 in } \\
\text { combination with } \\
\text { tremelimumab }\end{array}$ & $\begin{array}{l}\text { Currently } \\
\text { recruiting }\end{array}$ \\
\hline NCT02497508 & II & Nivolumab & 33 \\
\hline NCT02399371 & II & Pembrolizumab & $\begin{array}{l}\text { Currently } \\
\text { recruiting }\end{array}$ \\
\hline NCT02628067 & II & Pembrolizumab & $\begin{array}{l}\text { Currently } \\
\text { recruiting }\end{array}$ \\
\hline NCT02784171 & II & $\begin{array}{c}\text { Pembrolizumab, } \\
\text { cisplatin, pemetrexed }\end{array}$ & $\begin{array}{l}\text { Currently } \\
\text { recruiting }\end{array}$ \\
\hline NCT02458638 & II & Atezolizumab & $\begin{array}{l}\text { Currently } \\
\text { recruiting }\end{array}$ \\
\hline
\end{tabular}

\subsection{Multiple Targeted Therapies: Small Molecule and Antibody Approaches}

The increased understanding of molecular pathways involved in tumorigenesis allows for the development of valid rationales to specifically target malignant cells in solid tumours, including MPM (examples of trials of targeted therapies are listed in Table 3). It is well- 
known that proliferative signalling promotes tumour progression by releasing growth factors such as epidermal growth factor receptor (EGFR) which plays a pivotal role in proliferation and mediates cell growth by activating specific downstream pathways contributing to survival, differentiation, migration and adhesion. EGFR is part of the family of transmembrane tyrosine kinase receptors (TKRs), including platelet-derived growth factor receptors (PDGRs), fibroblast growth factor receptors (FGFRs) and vascular endothelial growth factor receptors (VEGFRs) ${ }^{76}$. The discovery of the role of this family prompted the development of tyrosinekinase inhibitors (TKIs), small molecules able to target the intracellular tyrosine kinase residue such as gefitinib and erlotinib which target EGFR (Fig 4).

In MPM, studies revealed that EGFR was overexpressed at the protein level in around 52\% of MPM patients ${ }^{77-79}$. The role of vascular endothelial growth factor (VEGF) and its receptor VEGFR has been identified in MPM, showing high levels of both molecules in tissue specimens ${ }^{80}$. Numerous inhibitors have been designed and tested in MM for these targets such as vatalanib, sorafenib, nintedanib, axitinib and cediranib and have shown limited or absent levels of activity, resulting in a lack of clinical benefits ${ }^{81,82}$. The most promising treatment to interact with VEFG signalling is bevacizumab (Avastin), a humanized monoclonal antibody against VEGFA which was approved in the EU in 2005 for the treatment of many solid cancers such as NSCLC, colorectal carcinoma, renal cell, and ovarian ${ }^{83-86}$ (Fig 4).

Moreover several small molecules acting as inhibitors have been developed for different pathways, including targets involved in epigenetic regulation of tumour suppressor genes, such as histone deacetylase (HDAC) inhibitors. The main agents tested in clinical trials are belinostat and vorinostat. Another strategy uses asparagine-glycine-arginine-human tumour necrosis factor $\alpha$ (NGR-hTNF) which is TNF-alpha fused with NGR. NGR is able to bind specifically an aminopeptidase $\mathrm{N}$ isoform overexpressed on tumour blood system ${ }^{87,88}$. FAK represents an encouraging target for MPM in particular due to its involvement in cancer stem cell (CSC) renewal ${ }^{89}$. Recently reported targeted therapies include RNA as a therapeutic target using ranpirnase, which promotes impaired protein synthesis and cell cycle arrest, leading to an antitumor activity ${ }^{90}$. Other targets and inhibitors include: heat shock protein 90 (HSP90) inhibitor (ganetespib); enhancer of zeste homolog 2 (EZH2) inhibitor (tazemetostat); inhibitor of the MET receptor tyrosine kinase (tivantinib); CSC inhibitor (napabucasin/BBI608) and TargomiRs (a mimic microRNA treatment).

\subsubsection{Phase I Clinical Trials}

A phase I study investigated the clinical profile of vorinostat in advanced tumours, including 13 patients with MPM ${ }^{91}$. The results of this study demonstrated there was no improved survival with the use of this drug. Although vorinostat has been tested in a phase III study as a second-line therapy, there was no improvement in OS and it cannot be suggested as an option for treatment for MPM patients in advanced stage ${ }^{92}$. A phase I study of TargomiRs, the first in human patients, has been designed to evaluate the best dose as second or third line treatment in 27 MPM and NSCLC patients (NCT02369198), though results are not yet published. 


\subsubsection{Phase II Clinical Trials}

Gefinitib (ZD1839, Iressa) is the main TKI studied in a clinical trial involving 40 malignant mesothelioma patients with unresectable disease but did not show any clinical benefit despite the fact that $97 \%$ of patients overexpressed EGFR (NCT00025207) ${ }^{93}$. Erlotinib, another TKI, did not improve survival in a study when used as a single agent in untreated patients ${ }^{94}$. Promising results have been reported from a study of erlotinib in combination with bevacizumab in pre-treated patients, showing a stable disease in $50 \%$ of patients, a PFS of 2.2 months and a median survival of 5.8 months (NCT00137826) ${ }^{95}$. Bevacizumab, one of the most promising anti-VEGF therapeutic agents, has been tested in combination with cisplatin plus gemcitabine in a multicentre study involving 108 chemo-naïve mesothelioma patients. PFS was 6.9 months for the bevacizumab arm versus 6 months for the placebo and OS was improved by only 1 month (15.6mo vs $14.7 \mathrm{mo}$ ) (NCT00027703). From these data, the conclusion is that bevacizumab does not improve PFS and OS ${ }^{96}$. However, an additional phase III study showed that bevacizumab in combination with pemetrexed and cisplatin improved OS by 2.7 months relative to pemetrexed and cisplatin alone ${ }^{97}$. A study of belinostat has been performed in patients with relapsed MPM but did not show activity in patients (NCT00365053) ${ }^{98}$. Defactinib (VS-6063) is a potent selective FAK inhibitor. A phase II randomized multicenter trial (COMMAND) of defactinib in previously treated MPM was initiated but the study has been terminated due to the lack of evidence that it is efficient (NCT01870609).

\subsection{Gene Therapy}

Another therapeutic approach under investigation for MPM is gene therapy which consists of the transfer of genetic material in cells for therapeutic purposes. In MPM, several genes have been detected to be interesting targets for gene therapy and different types of delivery systems have been clinically investigated to assess safety and activity in MPM patients ${ }^{99}$. MPM represents a promising target for gene therapy since the MPM tumour lining to the pleural cavity makes it easy to reach using in vivo gene delivery ${ }^{100}$. Although these trials have demonstrated good safety results, there has been relatively limited efficacy ${ }^{101}$.

\subsubsection{Suicide Gene Therapy}

Suicide gene therapy uses viruses to deliver a transgene which encode for a specific enzyme that is able to transform a prodrug into toxic metabolites, leading to tumour cell death or "suicide" 102 . The most commonly investigated approach is herpes simplex virus-1 thymidine kinase (HSVtk) gene which sensitises transduced cells to the nucleoside nontoxic antiviral drug ganciclovir ${ }^{99}$ (Fig 5A). 


\subsubsection{Cytokine Gene Therapy}

Cytokine gene therapy is a promising treatment since it has the ability to activate systemic, intrapleural, and intratumoral immune effector cells. Cytokine gene therapy is an improved technique to express increased amount of cytokines (such as IL-2, IL-12, TNF or INF - $\alpha$, $\beta$, or $\gamma$ ) using a viral vector with the advantage to reduce toxicity and increase the local concentration ${ }^{103}$ (Fig 5B).

\subsubsection{Phase I Clinical Trials}

Clinical trials assessing gene therapy for mesothelioma have been designed. One study tested transgene expression and clinical profiles in MPM patients receiving high-dose adenovirus HSVtk/ganciclovir suicide gene therapy ${ }^{104}$. The intrapleural administration was safe and well-tolerated in 34 patients but in only 2 patients long-term durable responses to the treatment were evident. Another study assessed the gene transfer, immune response profile and tumour response of single-dose intrapleural IFN- $\beta$ gene transfer using an adenoviral vector (Ad.IFN- $\beta$ ) in 10 mesothelioma patients, the results of which showed immune responses at a high rate ${ }^{105}$. A clinical trial testing adenoviral-mediated IFN- $\beta$ gene as a monotherapy for MPM patients is ongoing (NCT00299962). The first one is investigating two doses of the treatment whilst the second is a dose-escalation study. Currently an ongoing study "Autologous Redirected RNA Meso-CIR T Cells" is evaluating the safety and potential of Meso-CIR $T$ cells (autologous chimeric immune receptor $\mathrm{T}$ cells that have been transfected with an anti-mesothelin mRNA) in 18 patients (CT01355965).

Table 3: Phase I and II clinical trials for targeted and gene therapies.

\begin{tabular}{|c|c|c|c|}
\hline$\underline{\text { ClinicalTrials.gov }} \underline{\text { Identifier }}$ & Phase & $\underline{\text { Treatment }}$ & $\underline{\underline{\text { Number of }}}$ \\
\hline$\underline{\text { NCT00025207 }}$ & II & $\begin{array}{c}\text { Gefitinib (EGFR } \\
\text { inhibitor) }\end{array}$ \\
\hline$\underline{\text { NCT00137826 }}$ & II & $\begin{array}{c}\text { Bevacizumab (VEGF } \\
\text { inhibitor) and } \\
\text { erlotinib (EGFR } \\
\text { inhibitor) }\end{array}$ & 40 \\
\hline$\underline{\text { NCT00027703 }}$ & II & $\begin{array}{c}\text { Chemotherapy with or } \\
\text { without bevacizumab }\end{array}$ & 106 \\
\hline$\underline{\text { NCT00365053 }}$ & II & $\begin{array}{c}\text { Belinostat (HDAC } \\
\text { inhibitor) }\end{array}$ & 13 \\
\hline
\end{tabular}




\begin{tabular}{|c|c|c|c|}
\hline$\underline{\mathrm{NCT} 01870609}$ & II & $\begin{array}{c}\text { Defactinib (FAK } \\
\text { inhibitor) }\end{array}$ & 344 \\
\hline$\underline{\mathrm{NCT} 00299962}$ & I & $\begin{array}{c}\text { Adenoviral-mediated } \\
\text { IFN } \beta\end{array}$ & $\begin{array}{c}18 \text { (estimated, } \\
\text { study ongoing) }\end{array}$ \\
\hline$\underline{\mathrm{NCT} 01355965}$ & I & $\begin{array}{c}\text { Redirected RNA } \\
\text { Meso-CIR } \\
\text { Autologous T Cells }\end{array}$ & 18 \\
\hline
\end{tabular}

\section{Expert Opinion}

There is no doubt that in the last few years more effort has been placed in developing and testing new therapeutic options for mesothelioma. Unfortunately the major weakness of this (welcome) interest has been the idea that therapies with some activity for other tumours could be applied "tout court" to mesothelioma. It is clear that this approach is not based on a solid understanding of mesothelioma biology and it is questionable that it islikely to achieve significant results.

Among others factors, it is our opinion that taking the hypoxic microenvironment of mesothelioma into account can assist in the development of much more "mesothelioma tailored" therapies ${ }^{106}$. With regard to what the clinical trials for mesothelioma so far have shown as the "best result" underpinning the front line therapy for this neoplasm is based on a trial that allows a gain of survival of 2.7 months and on a preclinical study previously published by our group 97,107 .

Hence rather than discussing what the most promising results of treatment for this tumour have been so far we should ask ourselves why we have not achieved more significant steps forward yet. A more precise focus on mesothelioma biology (encompassing genetics, metabolomics and functional studies) conducted on cell models closer to the in vivo events in primary tumour cell lines and 3D studies could foster our clinical impact. It is clear that surrogate end points such as progression-free survival do not mirror the real clinical effect of any novel treatment in oncology ${ }^{108}$. Our purpose should be that of extending mesothelioma patient survival by longer than three months.

This is particularly true for immunotherapy as recently demonstrated by the failure of clinical trials for mesothelioma with OS as a primary end point (in spite of some efficacy of the phase II trials) and, more generally, by the low number of patients who can truly benefit from immune checkpoint inhibitors. Moreover, the purely "genetic" approach to cancer treatment is currently being discussed and evaluated. This approach is even more contentious when one looks at the low mutational load of MPM ${ }^{108,109 .}$

We believe that only a more integrated and balanced approach to MPM will allow us to get ahead and achieve more significant clinical results. This should encompass multiple disciplines such as genetics, biochemistry and immunology that are already applied to cancer research and be even more focused on MPM than done so far. A more precise understanding of how the stroma may affect the response to therapy is also an important area and offers a 
novel therapeutic target ${ }^{53,110}$. The effect of the microenvironment and the subsequent MPM metabolic reprogramming offers a unique scenario with potentially significant therapeutic implications for this orphan disease (manuscript in preparation).

Ultimately magic bullets do not exist in oncology but we are confident that an unbiased multidisciplinary approach to this tumour could allow us to achieve significant results sooner than expected. Metabolic reprogramming of tumour cells, the hypoxic microenvironment and the stroma are all areas that offer promising points of interest for therapeutic development.

\section{Conflict of Interest Statement}

All authors have nothing to disclose. 


\section{References}

1. Robinson BW, Lake RA. Advances in malignant mesothelioma. The New England journal of medicine 2005 Oct 13;353(15):1591-603.

2. Sekido Y. Molecular pathogenesis of malignant mesothelioma. Carcinogenesis 2013 Jul;34(7):1413-9.

**General overview of mesothelioma by Sekido.

3. Yang H, Testa JR, Carbone M. Mesothelioma epidemiology, carcinogenesis, and pathogenesis. Current treatment options in oncology 2008 Jun;9(2-3):147-57.

4. Testa JR, Cheung M, Pei J, Below JE, Tan Y, Sementino E, et al. Germline BAP1 mutations predispose to malignant mesothelioma. Nature genetics 2011 Aug 28;43(10):10225.

5. Ahmed I, Ahmed Tipu S, Ishtiaq S. Malignant mesothelioma. Pak J Med Sci 2013 Nov;29(6):1433-8.

6. Haas AR, Sterman DH. Malignant pleural mesothelioma: update on treatment options with a focus on novel therapies. Clin Chest Med 2013 Mar;34(1):99-111.

7. Park EK, Takahashi K, Hoshuyama T, Cheng TJ, Delgermaa V, Le GV, et al. Global magnitude of reported and unreported mesothelioma. Environ Health Perspect 2011 Apr;119(4):514-8.

8. Bibby AC, Tsim S, Kanellakis N, Ball H, Talbot DC, Blyth KG, et al. Malignant pleural mesothelioma: an update on investigation, diagnosis and treatment. Eur Respir Rev 2016 Dec 1;25(142):472-86.

9. Farkona S, Diamandis EP, Blasutig IM. Cancer immunotherapy: the beginning of the end of cancer? BMC medicine 2016 May 05;14:73.

10. Wong RM, Ianculescu I, Sharma S, Gage DL, Olevsky OM, Kotova S, et al. Immunotherapy for Malignant Pleural Mesothelioma Current Status and Future Prospects.

Am J Resp Cell Mol 2014 May;50(5):870-75.

11. June $\mathrm{CH}$. Adoptive $\mathrm{T}$ cell therapy for cancer in the clinic. Journal of Clinical Investigation 2007;117(6):1466-76.

12. Emens LA, Middleton G. The Interplay of Immunotherapy and Chemotherapy: Harnessing Potential Synergies. Cancer immunology research 2015 May;3(5):436-43.

13. Doyle C. Combination Immunotherapy Superior to Monotherapy in Patients with Melanoma. American Health \& Drug Benefits 2015;8(Spec Issue):41-41.

14. Butterfield LH. Cancer vaccines. Bmj 2015 Apr 22;350:h988.

15. Kumar C, Kohli S, Bapsy PP, Vaid AK, Jain M, Attili VS, et al. Immune modulation by dendritic-cell-based cancer vaccines. Journal of biosciences 2017 Mar;42(1):161-73.

16. Palucka K, Banchereau J. Dendritic-Cell-Based Therapeutic Cancer Vaccines. Immunity 2013 Jul 25;39(1):38-48.

*Useful article on DC-based vaccines by Palucka and colleagues.

17. Cheever MA, Higano CS. PROVENGE (Sipuleucel-T) in Prostate Cancer: The First FDA-Approved Therapeutic Cancer Vaccine. Clin Cancer Res 2011 Jun 1;17(11):3520-26. 18. Hammerstrom AE, Cauley DH, Atkinson BJ, Sharma P. Cancer Immunotherapy: Sipuleucel-T and Beyond. Pharmacotherapy 2011;31(8):813-28.

19. Le DT, Dubensky TW, Brockstedt DG. Clinical Development of Listeria monocytogenes-Based Immunotherapies. Seminars in oncology 2012;39(3):311-22. 
20. Chiang CL-L, Coukos G, Kandalaft LE. Whole Tumor Antigen Vaccines: Where Are We? Vaccines 2015 04/23

\section{1/08/received}

04/16/accepted;3(2):344-72.

21. Guo C, Manjili MH, Subjeck JR, Sarkar D, Fisher PB, Wang XY. Therapeutic cancer vaccines: past, present, and future. Advances in cancer research 2013;119:421-75.

22. Huff V. Wilms' tumours: about tumour suppressor genes, an oncogene and a chameleon gene. Nat Rev Cancer 2011 Feb;11(2):111-21.

23. Sugiyama H. WT1 (Wilms' tumor gene 1): biology and cancer immunotherapy. Japanese journal of clinical oncology 2010 May;40(5):377-87.

24. Wurz GT, Kao CJ, DeGregorio MW. Novel cancer antigens for personalized immunotherapies: latest evidence and clinical potential. Ther Adv Med Oncol 2016 Jan;8(1):4-31.

25. Hegmans LPJJ, Hemmes A, Aerts JG, Hoogsteden HC, Lambrecht BN.

Immunotherapy of murine malignant mesothelioma using tumor lysate-pulsed dendritic cells. Am J Resp Crit Care 2005 May 15;171(10):1168-77.

26. Hegmans JP, Veltman JD, Lambers ME, de Vries IJM, Figdor CG, Hendricks RW, et al. Consolidative Dendritic Cell-based Immunotherapy Elicits Cytotoxicity against Malignant Mesothelioma. Am J Resp Crit Care 2010 Jun 15;181(12):1383-90.

27. Cornelissen R, Hegmans JP, Maat AP, Kaijen-Lambers ME, Bezemer K, Hendriks RW, et al. Extended Tumor Control after Dendritic Cell Vaccination with Low-Dose Cyclophosphamide as Adjuvant Treatment in Patients with Malignant Pleural Mesothelioma. Am J Respir Crit Care Med 2016 May 01;193(9):1023-31.

28. Krug LM, Dao T, Brown AB, Maslak P, Travis W, Bekele S, et al. WT1 peptide vaccinations induce CD4 and CD8 T cell immune responses in patients with mesothelioma and non-small cell lung cancer. Cancer Immunol Immun 2010 Oct;59(10):1467-79.

*Informative article on WT-1 vaccines by Krug and colleagues.

29. Powell A, Creaney J, Broornfield S, Van Bruggen I, Robinson B. Recombinant GMCSF plus autologous tumor cells as a vaccine for patients with mesothelioma. Lung Cancer-J Iaslc 2006 May;52(2):189-97.

30. Jahan T, Hassan R, Alley E, Kindler H, Antonia S, Whiting C, et al. 208O_PR: CRS207 with chemotherapy (chemo) in malignant pleural mesothelioma (MPM): Results from a phase $1 \mathrm{~b}$ trial. Journal of thoracic oncology : official publication of the International Association for the Study of Lung Cancer 2016 Apr;11(4 Suppl):S156.

31. Sapra P, Shor B. Monoclonal antibody-based therapies in cancer: advances and challenges. Pharmacology \& therapeutics 2013 Jun;138(3):452-69.

32. Grillo-Lopez AJ, White CA, Varns C, Shen D, Wei A, McClure A, et al. Overview of the clinical development of rituximab: first monoclonal antibody approved for the treatment of lymphoma. Semin Oncol 1999 Oct;26(5 Suppl 14):66-73.

33. Cristaudo A, Foddis R, Vivaldi A, Guglielmi G, Dipalma N, Filiberti R, et al. Clinical significance of serum mesothelin in patients with mesothelioma and lung cancer. Clin Cancer Res 2007 Sep 01;13(17):5076-81.

34. Villena-Vargas J, Adusumilli PS. Mesothelin-targeted immunotherapies for malignant pleural mesothelioma. Annals of cardiothoracic surgery 2012 Nov;1(4):466-71.

*Useful information on mesothelin and its place in mesothelioma therapy by Villena-Vargas and colleagues. 
35. Chopra A. 111In-Labeled CHX-A"-DTPA-conjugated MORAb-009, a chimeric monoclonal antibody directed against mesothelin. Molecular Imaging and Contrast Agent Database (MICAD). Bethesda (MD) 2004.

36. Hassan R, Ebel W, Routhier EL, Patel R, Kline JB, Zhang J, et al. Preclinical evaluation of MORAb-009, a chimeric antibody targeting tumor-associated mesothelin. Cancer immunity 2007 Dec 19;7:20.

37. Golfier S, Kopitz C, Kahnert A, Heisler I, Schatz CA, Stelte-Ludwig B, et al. Anetumab Ravtansine: A Novel Mesothelin-Targeting Antibody-Drug Conjugate Cures Tumors with Heterogeneous Target Expression Favored by Bystander Effect. Mol Cancer Ther 2014 Jun;13(6):1537-48.

38. Lonning S, Mannick J, McPherson JM. Antibody targeting of TGF-beta in cancer patients. Current pharmaceutical biotechnology 2011 Dec;12(12):2176-89.

39. Massague J. TGFbeta in Cancer. Cell 2008 Jul 25;134(2):215-30.

40. Stevenson JP, Kindler HL, Papasavvas E, Sun J, Jacobs-Small M, Hull J, et al. Immunological effects of the TGF $\beta$-blocking antibody GC1008 in malignant pleural mesothelioma patients. Oncoimmunology 2013 08/27

06/10/received

08/05/revised

08/06/accepted;2(8):e26218.

41. Chames P, Van Regenmortel M, Weiss E, Baty D. Therapeutic antibodies: successes, limitations and hopes for the future. Brit J Pharmacol 2009 May;157(2):220-33.

42. Gregoire M. What's the place of immunotherapy in malignant mesothelioma treatments? Cell adhesion \& migration 2010 Jan-Mar;4(1):153-61.

** Detailed review of immunotherapy in mesothelioma

43. Klapper JA, Downey SG, Smith FO, Yang JC, Hughes MS, Kammula US, et al. High-dose interleukin-2 for the treatment of metastatic renal cell carcinoma - A retrospective analysis of response and survival in patients treated in the Surgery Branch at the National Cancer Institute between 1986 and 2006. Cancer 2008 Jul 15;113(2):293-301.

44. Boutin C, Nussbaum E, Monnet I, Bignon J, Vanderschueren R, Guerin JC, et al. Intrapleural Treatment with Recombinant Gamma-Interferon in Early-Stage Malignant Pleural Mesothelioma. Cancer 1994 Nov 1;74(9):2460-67.

45. Kreitman RJ, Hassan R, Fitzgerald DJ, Pastan I. Phase I trial of continuous infusion anti-mesothelin recombinant immunotoxin SS1P. Clin Cancer Res 2009 Aug 15;15(16):52749.

46. Hassan R, Sharon E, Thomas A, Zhang J, Ling A, Miettinen M, et al. Phase 1 study of the antimesothelin immunotoxin SS1P in combination with pemetrexed and cisplatin for front-line therapy of pleural mesothelioma and correlation of tumor response with serum mesothelin, megakaryocyte potentiating factor, and cancer antigen 125. Cancer 2014 Nov 01;120(21):3311-9.

47. Hassan R, Cohen SJ, Phillips M, Pastan I, Sharon E, Kelly RJ, et al. Phase I clinical trial of the chimeric anti-mesothelin monoclonal antibody MORAb-009 in patients with mesothelin-expressing cancers. Clin Cancer Res 2010 Dec 15;16(24):6132-8.

48. Fujisaka Y, Kurata T, Tanaka K, Kudo T, Okamoto K, Tsurutani J, et al. Phase I study of amatuximab, a novel monoclonal antibody to mesothelin, in Japanese patients with advanced solid tumors. Investigational new drugs 2015 Apr;33(2):380-8. 
49. Hassan R, Kindler HL, Jahan T, Bazhenova L, Reck M, Thomas A, et al. Phase II clinical trial of amatuximab, a chimeric antimesothelin antibody with pemetrexed and cisplatin in advanced unresectable pleural mesothelioma. Clin Cancer Res 2014 Dec 01;20(23):5927-36.

50. Ho WY, Blattman JN, Dossett ML, Yee C, Greenberg PD. Adoptive immunotherapy: Engineering $\mathrm{T}$ cell responses as biologic weapons for tumor mass destruction. Cancer Cell 2003 May;3(5):431-37.

51. Lee DW, Barrett DM, Mackall C, Orentas R, Grupp SA. The Future Is Now: Chimeric Antigen Receptors as New Targeted Therapies for Childhood Cancer. Clinical cancer research : an official journal of the American Association for Cancer Research 2012;18(10):2780-90.

52. Carpenito C, Milone MC, Hassan R, Simonet JC, Lakhal M, Suhoski MM, et al. Control of large, established tumor xenografts with genetically retargeted human T cells containing CD28 and CD137 domains. Proceedings of the National Academy of Sciences of the United States of America 2009 Mar 03;106(9):3360-5.

53. Schuberth PC, Hagedorn C, Jensen SM, Gulati P, van den Broek M, Mischo A, et al. Treatment of malignant pleural mesothelioma by fibroblast activation protein-specific redirected T cells. Journal of translational medicine 2013 Aug 12;11:187.

54. Bakker E, Guazzelli A, Krstic-Demonacos M, Lisanti M, Sotgia F, Mutti L. Current and prospective pharmacotherapies for the treatment of pleural mesothelioma. Expert Opinion on Orphan Drugs 2017 2017/06/03;5(6):455-65.

55. Wu R, Forget MA, Chacon J, Bernatchez C, Haymaker C, Chen JQ, et al. Adoptive TCell Therapy Using Autologous Tumor-Infiltrating Lymphocytes for Metastatic Melanoma Current Status and Future Outlook. Cancer J 2012 Mar-Apr;18(2):160-75.

56. Guazzelli A, Bakker E, Krstic-Demonacos M, Lisanti MP, Sotgia F, Mutti L. AntiCTLA-4 therapy for malignant mesothelioma. Immunotherapy 2017 Mar;9(3):273-80.

57. Bakker E, Qattan M, Mutti L, Demonacos C, Krstic-Demonacos M. The role of microenvironment and immunity in drug response in leukemia. Biochimica et biophysica acta 2016 Mar;1863(3):414-26.

58. Postow MA, Callahan MK, Wolchok JD. Immune Checkpoint Blockade in Cancer Therapy. J Clin Oncol 2015 Jun 10;33(17):1974-U161.

**General overview of immune checkpoint blockade in cancer by Postow and colleagues.

59. Valk E, Rudd CE, Schneider H. CTLA-4 trafficking and surface expression. Trends Immunol 2008 Jun;29(6):272-79.

60. Waterhouse P, Penninger JM, Timms E, Wakeham A, Shahinian A, Lee KP, et al. Lymphoproliferative Disorders with Early Lethality in Mice Deficient in Ctla-4. Science 1995 Nov 10;270(5238):985-88.

61. Leach DR, Krummel MF, Allison JP. Enhancement of antitumor immunity by CTLA4 blockade. Science 1996 Mar 22;271(5256):1734-6.

62. Specenier P. Ipilimumab in melanoma. Expert Rev Anticanc 2016 Aug;16(8):811-26.

63. Guazzelli A, Hussain M, Krstic-Demonacos M, Mutti L. Tremelimumab for the treatment of malignant mesothelioma. Expert opinion on biological therapy 2015;15(12):1819-29.

64. Selby MJ, Engelhardt JJ, Johnston RJ, Lu LS, Han M, Thudium K, et al. Preclinical Development of Ipilimumab and Nivolumab Combination Immunotherapy: Mouse Tumor Models, In Vitro Functional Studies, and Cynomolgus Macaque Toxicology. PloS one 2016;11(9):e0161779. 
65. Ansell SM. Nivolumab in the Treatment of Hodgkin Lymphoma. Clin Cancer Res 2016 Nov 23.

66. Beaver JA, Theoret MR, Mushti S, He K, Libeg M, Goldberg K, et al. FDA Approval of Nivolumab for the First-Line Treatment of Patients with BRAFV600 Wild-Type Unresectable or Metastatic Melanoma. Clin Cancer Res 2017 Jan 10.

67. Kazandjian D, Suzman DL, Blumenthal G, Mushti S, He K, Libeg M, et al. FDA Approval Summary: Nivolumab for the Treatment of Metastatic Non-Small Cell Lung Cancer With Progression On or After Platinum-Based Chemotherapy. The oncologist 2016 May;21(5):634-42.

68. Chang R, Shirai K. Safety and efficacy of pembrolizumab in a patient with advanced melanoma on haemodialysis. BMJ case reports 2016 Sep 22;2016.

69. Bansal P, Osman D, Gan GN, Simon GR, Boumber Y. Recent Advances in Immunotherapy in Metastatic NSCLC. Frontiers in oncology 2016;6:239.

70. Loo D, Alderson RF, Chen FZ, Huang L, Zhang WJ, Gorlatov S, et al. Development of an Fc-Enhanced Anti-B7-H3 Monoclonal Antibody with Potent Antitumor Activity. Clin Cancer Res 2012 Jul 15;18(14):3834-45.

71. Mao L, Fan T-F, Wu L, Yu G-T, Deng W-W, Chen L, et al. Selective blockade of B7$\mathrm{H} 3$ enhances antitumour immune activity by reducing immature myeloid cells in head and neck squamous cell carcinoma. Journal of Cellular and Molecular Medicine 2017:n/a-n/a. 72. Alley EW, Lopez J, Santoro A, Morosky A, Saraf S, Piperdi B, et al. Clinical safety and activity of pembrolizumab in patients with malignant pleural mesothelioma (KEYNOTE028): preliminary results from a non-randomised, open-label, phase $1 \mathrm{~b}$ trial. Lancet Oncology 2017 May;18(5):623-30.

73. Calabro L, Morra A, Fonsatti E, Cutaia O, Amato G, Giannarelli D, et al. Tremelimumab for patients with chemotherapy-resistant advanced malignant mesothelioma: an open-label, single-arm, phase 2 trial. The Lancet Oncology 2013 Oct;14(11):1104-11. 74. Calabro L, Morra A, Fonsatti E, Cutaia O, Fazio C, Annesi D, et al. Efficacy and safety of an intensified schedule of tremelimumab for chemotherapy-resistant malignant mesothelioma: an open-label, single-arm, phase 2 study. The Lancet Respiratory medicine 2015 Apr;3(4):301-9.

75. Quispel-Janssen J, Zago G, Schouten R, Buikhuisen W, Monkhorst K, Thunissen E, et al. OA13.01 A Phase II Study of Nivolumab in Malignant Pleural Mesothelioma (NivoMes): with Translational Research (TR) Biopies. Journal of Thoracic Oncology 2017;12(1):S292S93.

76. Hubbard SR, Miller WT. Receptor tyrosine kinases: mechanisms of activation and signaling. Curr Opin Cell Biol 2007 Apr;19(2):117-23.

77. Destro A, Ceresoli GL, Falleni M, Zucali PA, Morenghi E, Bianchi P, et al. EGFR overexpression in malignant pleural mesothelioma. An immunohistochemical and molecular study with clinico-pathological correlations. Lung Cancer-J Iaslc 2006 Feb;51(2):207-15. 78. Enomoto Y, Kasai T, Takeda M, Takano M, Morita K, Kadota E, et al. Epidermal growth factor receptor mutations in malignant pleural and peritoneal mesothelioma. J Clin Pathol 2012 Jun;65(6):522-27.

79. Rena O, Boldorini LR, Gaudino E, Casadio C. Epidermal growth factor receptor overexpression in malignant pleural mesothelioma: prognostic correlations. Journal of surgical oncology 2011 Nov 01;104(6):701-5.

80. Demirag F, Unsal E, Yilmaz A, Caglar A. Prognostic significance of vascular endothelial growth factor, tumor necrosis, and mitotic activity index in malignant pleural mesothelioma. Chest 2005 Nov;128(5):3382-7. 
81. Jahan T, Gu L, Kratzke R, Dudek A, Otterson GA, Wang XF, et al. Vatalanib in malignant mesothelioma: A phase II trial by the Cancer and Leukemia Group B (CALGB 30107). Lung Cancer-J Iaslc 2012 Jun;76(3):393-96.

82. Dubey S, Janne PA, Krug L, Pang H, Wang XF, Heinze R, et al. A Phase II Study of Sorafenib in Malignant Mesothelioma Results of Cancer and Leukemia Group B 30307. Journal of Thoracic Oncology 2010 Oct;5(10):1655-61.

83. Cohen MH, Gootenberg J, Keegan P, Pazdur R. FDA drug approval summary: Bevacizumab (Avastin (R)) plus carboplatin and paclitaxel as first-line treatment of advanced/metastatic recurrent nonsquamous non-small cell lung cancer. The oncologist 2007;12(6):713-18.

84. Koukourakis GV, Sotiropoulou-Lontou A. Targeted therapy with bevacizumab (Avastin) for metastatic colorectal cancer. Clin Transl Oncol 2011 Oct;13(10):710-14. 85. Escudier B, Cosaert J, Jethwa S. Targeted therapies in the management of renal cell carcinoma: role of bevacizumab. Biologics : Targets \& Therapy 2008 09/;2(3):517-30. 86. Della Pepa C, Banerjee S. Bevacizumab in combination with chemotherapy in platinum-sensitive ovarian cancer. Oncotargets Ther 2014;7:1025-32.

87. Chu W-M. Tumor necrosis factor. Cancer letters 2013 10/22;328(2):222-25.

88. Gregorc V, Zucali PA, Santoro A, Ceresoli GL, Citterio G, De Pas TM, et al. Phase II study of asparagine-glycine-arginine-human tumor necrosis factor alpha, a selective vascular targeting agent, in previously treated patients with malignant pleural mesothelioma. J Clin Oncol 2010 May 20;28(15):2604-11.

89. Sulzmaier FJ, Jean C, Schlaepfer DD. FAK in cancer: mechanistic findings and clinical applications. Nat Rev Cancer 2014 Sep;14(9):598-610.

90. Porta C, Paglino C, Mutti L. Ranpirnase and its potential for the treatment of unresectable malignant mesothelioma. Biologics 2008 Dec;2(4):601-9.

91. Kelly WK, O'Connor OA, Krug LM, Chiao JH, Heaney M, Curley T, et al. Phase I study of an oral histone deacetylase inhibitor, suberoylanilide hydroxamic acid, in patients with advanced cancer. J Clin Oncol 2005 Jun 10;23(17):3923-31.

92. Bronte G, Incorvaia L, Rizzo S, Passiglia F, Galvano A, Rizzo F, et al. The resistance related to targeted therapy in malignant pleural mesothelioma: Why has not the target been hit yet? Crit Rev Oncol Hemat 2016 Nov; 107:20-32.

93. Govindan R, Kratzke RA, Herndon JE, 2nd, Niehans GA, Vollmer R, Watson D, et al. Gefitinib in patients with malignant mesothelioma: a phase II study by the Cancer and Leukemia Group B. Clin Cancer Res 2005 Mar 15;11(6):2300-4.

94. Garland LL, Rankin C, Gandara DR, Rivkin SE, Scott KM, Nagle RB, et al. Phase II study of erlotinib in patients with malignant pleural mesothelioma: a Southwest Oncology Group Study. J Clin Oncol 2007 Jun 10;25(17):2406-13.

95. Jackman DM, Kindler HL, Yeap BY, Fidias P, Salgia R, Lucca J, et al. Erlotinib plus bevacizumab in previously treated patients with malignant pleural mesothelioma. Cancer 2008 Aug 15;113(4):808-14.

96. Kindler HL, Karrison TG, Gandara DR, Lu C, Krug LM, Stevenson JP, et al.

Multicenter, Double-Blind, Placebo-Controlled, Randomized Phase II Trial of Gemcitabine/Cisplatin Plus Bevacizumab or Placebo in Patients With Malignant Mesothelioma. J Clin Oncol 2012 Jul 10;30(20):2509-15.

97. Zalcman G, Mazieres J, Margery J, Greillier L, Audigier-Valette C, Moro-Sibilot D, et al. Bevacizumab for newly diagnosed pleural mesothelioma in the Mesothelioma Avastin Cisplatin Pemetrexed Study (MAPS): a randomised, controlled, open-label, phase 3 trial. Lancet (London, England) 2016 Apr 02;387(10026):1405-14.

*Important study on bevacizumab in mesothelioma 
98. Ramalingam SS, Belani CP, Ruel C, Frankel P, Gitlitz B, Koczywas M, et al. Phase II Study of Belinostat (PXD101), a Histone Deacetylase Inhibitor, for Second Line Therapy of Advanced Malignant Pleural Mesothelioma. Journal of Thoracic Oncology 2009 Jan;4(1):97101.

99. Vachani A, Moon E, Albelda SM. Gene therapy for mesothelioma. Current treatment options in oncology 2011 Jun;12(2):173-80.

100. van der Most RG, Robinson BWS, Nelson DJ. Gene therapy for malignant mesothelioma: beyond the infant years. Cancer Gene Ther 2006 Oct;13(10):897-904.

101. Vachani A, Sterman DH, Albelda SM. Cytokine gene therapy for malignant pleural mesothelioma. Journal of thoracic oncology : official publication of the International Association for the Study of Lung Cancer 2007 Apr;2(4):265-7.

102. Zarogoulidis P, Darwiche K, Sakkas A, Yarmus L, Huang H, Li Q, et al. Suicide Gene Therapy for Cancer - Current Strategies. Journal of genetic syndrome \& gene therapy 2013;4:16849.

103. Qian C, Liu XY, Prieto J. Therapy of cancer by cytokines mediated by gene therapy approach. Cell Res 2006 Feb;16(2):182-88.

104. Sterman DH, Recio A, Vachani A, Sun J, Cheung L, DeLong P, et al. Long-term follow-up of patients with malignant pleural mesothelioma receiving high-dose adenovirus herpes simplex thymidine kinase/ganciclovir suicide gene therapy. Clin Cancer Res 2005 Oct 15;11(20):7444-53.

105. Sterman DH, Kanther M. A phase I clinical trial of single-dose intrapleural IFN-beta gene transfer for malignant pleural mesothelioma and metastatic pleural effusions: High rate of antitumor immune responses (vol 13, pg 4456, 2007). Clin Cancer Res 2007 Sep 1;13(17):5226-26.

106. Nabavi N, Bennewith KL, Churg A, Wang Y, Collins CC, Mutti L. Switching off malignant mesothelioma: exploiting the hypoxic microenvironment. Genes Cancer 2016 Nov;7(11-12):340-54.

107. Strizzi L, Catalano A, Vianale G, Orecchia S, Casalini A, Tassi G, et al. Vascular endothelial growth factor is an autocrine growth factor in human malignant mesothelioma. $\mathrm{J}$ Pathol 2001 Apr;193(4):468-75.

108. Tan A, Porcher R, Crequit P, Ravaud P, Dechartres A. Differences in Treatment Effect Size Between Overall Survival and Progression-Free Survival in Immunotherapy Trials: A Meta-Epidemiologic Study of Trials With Results Posted at ClinicalTrials.gov. J Clin Oncol 2017 Apr 04:JCO2016712109.

109. Abola MV, Prasad V. The Use of Superlatives in Cancer Research. Jama Oncol 2016 Jan;2(1):139-41.

110. Feig C, Jones JO, Kraman M, Wells RJ, Deonarine A, Chan DS, et al. Targeting CXCL12 from FAP-expressing carcinoma-associated fibroblasts synergizes with anti-PD-L1 immunotherapy in pancreatic cancer. Proceedings of the National Academy of Sciences of the United States of America 2013 Dec 10;110(50):20212-7. 
Figure 1

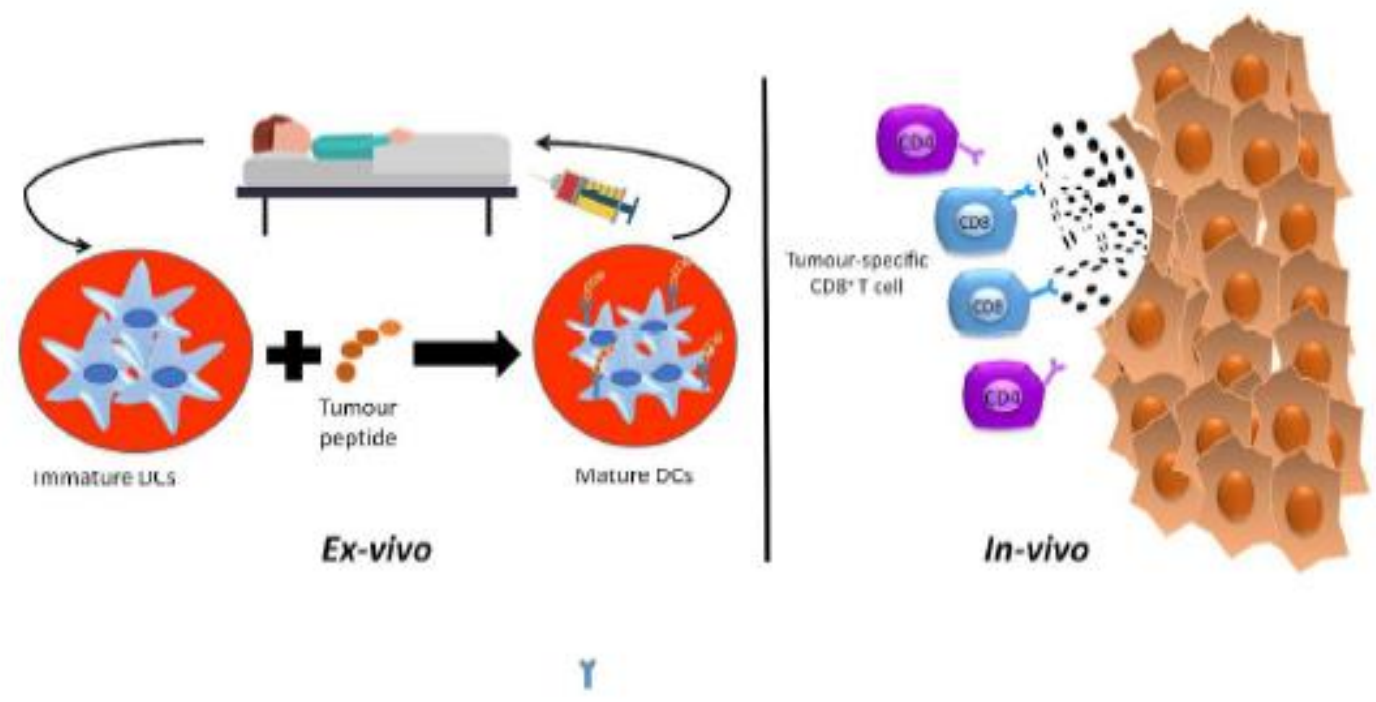

Figure 1. Passive Immunotherapy: Dendritic cell-based vaccines are developed by isolating immature dendritic cells from the patient and incubating them ex- vivo with tumour lysate. Mature DCs are injected back to the same patient to induce a tumour-specific immune response by activating tumourspecific CD8+ T cells. 
Figure 2

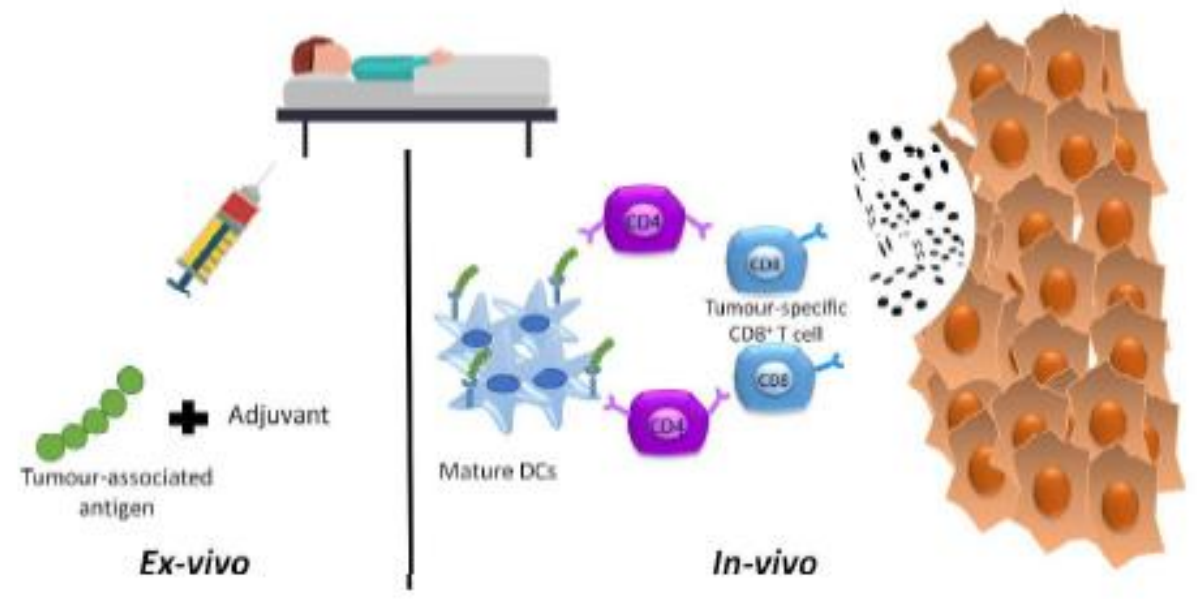

Figure 2. Peptide-based vaccines are single peptides or a cocktail of peptides obtained from cancer cells of patients and are amplified ex-vivo. These peptides are conjugated to an adjuvant and are injected back to the patient. DCs endocytose these peptides and present them and activate CD4+ cells which subsequently induce CD8+ CTL specific anti-tumour immune response. 


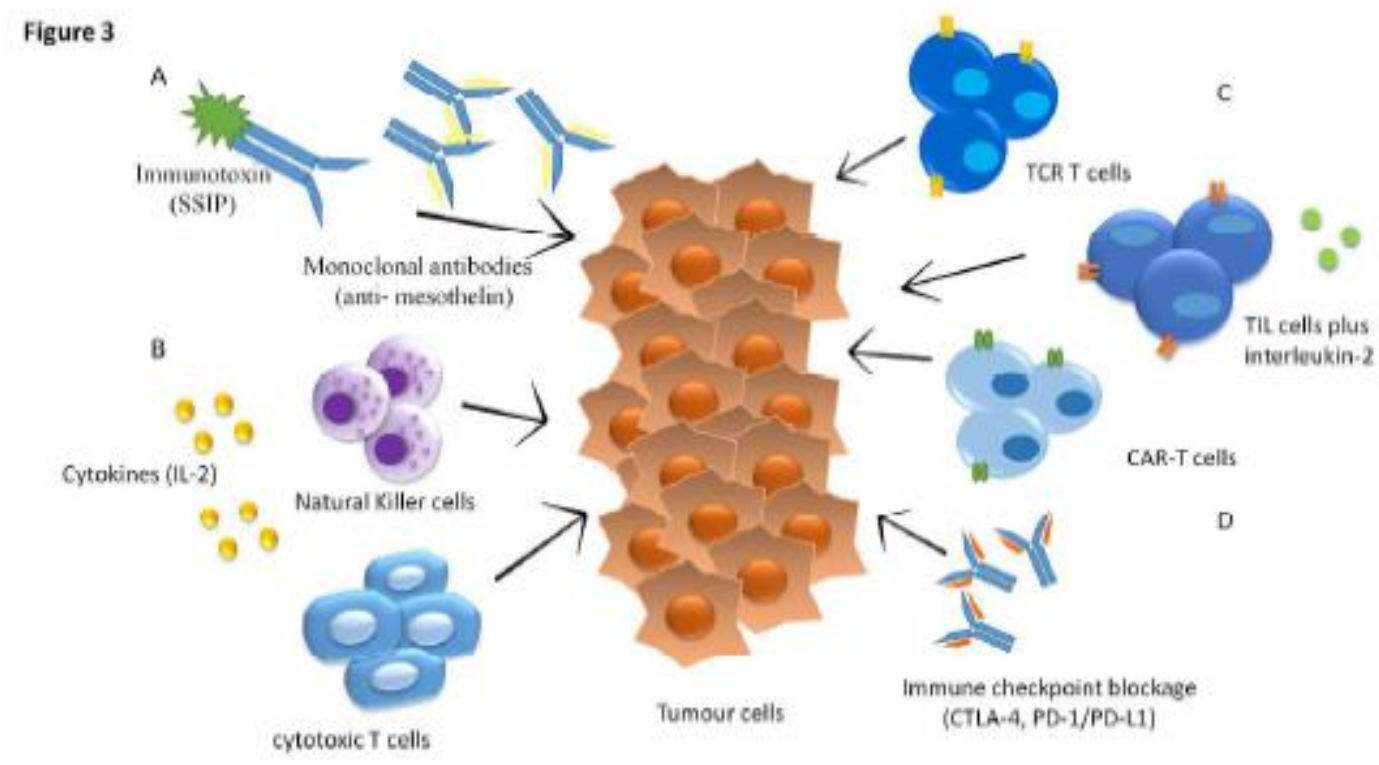

Figure 3: Schematic representation of passive immunotherapeutic strategies. A) antibody-based strategy using monoclonal antibodies or immunotoxins against cancer cells (mesothelin is the main target for mesothelioma). B) Cytokine-based therapy provides cytotoxic immune response by activating natural killer (NK) cells or tumour-specific cytotoxic T cells. C) Adoptive T cells therapy uses engineered T cells expressing T-cell receptor (TCR), Tumour infiltrating lymphocytes (TIL) combined with interleukin-2 or a chimeric antigen receptor (CAR) to interact with cancer cells; D) In immune checkpoint blockade approach monoclonal antibodies specifically recognizing receptors such as the cytotoxic T-lymphocyte antigen 4 (CTLA-4) receptor or the programmed death-1/programmed death ligand-1 (PD1/PDL-1) are used to block the function of these receptors. 
Figure 4
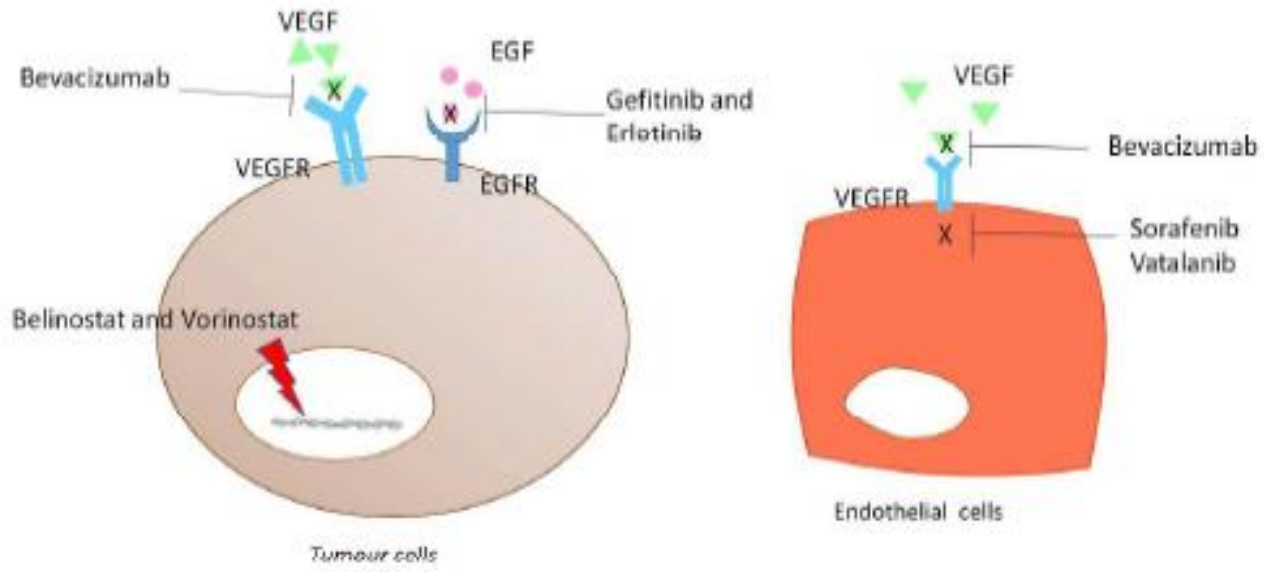

Figure 4. Graphic representation of anticancer multiple targeted approaches in MM. Belinostat and vorinostat induce DNA damage whereas the antibodies bevacizumab, gefitinib and erlotinib prevent the binding of VEGF and EGF respectively to their receptors thereby inhibiting their intracellular signalling. Bevacizumab functions extracellularly whereas the small molecules sorafenib and vatalanib inhibit the VEGFR intracellular signalling. 
Figure 5
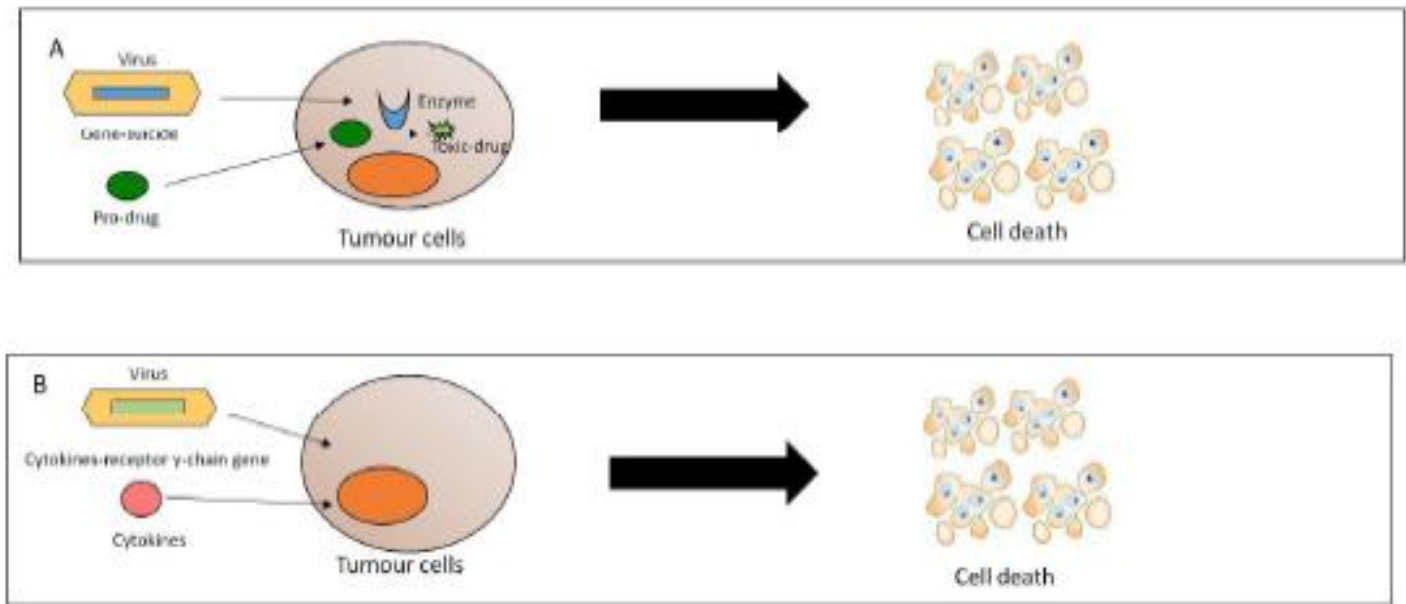

Figure 5. Summary of gene therapies for MM treatment. A) Suicide gene therapy: tumour cells modified to express a specific enzyme to metabolise a prodrug into a cytotoxic product to induce tumour cell death; B) Cytokine gene therapy: expression of cytokines to activate a more effective immune response. 